\title{
Differentiation of Confectionery Products Based on Mineral Composition
}

\author{
Malgorzata Grembecka • Piotr Szefer
}

Received: 22 December 2010 / Accepted: 28 March 2011/Published online: 12 April 2011

(C) The Author(s) 2011. This article is published with open access at Springerlink.com

\begin{abstract}
The aim of this investigation was to introduce multivariate techniques for the estimation of confectionery product quality in view of their mineral composition. The concentrations of 14 elements $(\mathrm{Ca}, \mathrm{Mg}, \mathrm{K}, \mathrm{Na}, \mathrm{P}, \mathrm{Co}, \mathrm{Mn}$, $\mathrm{Fe}, \mathrm{Cr}, \mathrm{Ni}, \mathrm{Zn}, \mathrm{Cu}, \mathrm{Cd}$, and $\mathrm{Pb}$ ) were determined in confectionery products after wet digestion with nitric acid in an automatic microwave digestion system. The total metal contents were analyzed by flame atomic absorption spectrometry using deuterium background correction. Phosphorus was determined in the form of phosphomolybdate by a spectrophotometric method. Reliability of the procedure was checked by analysis of the certified reference materials tea (NCS DC 73351), cabbage (IAEA-359), and spinach (IAEA-331). Significant correlation coefficients were found between concentrations of $\mathrm{Mg}, \mathrm{Zn}, \mathrm{Ca}, \mathrm{K}, \mathrm{Na}$, $\mathrm{P}$, and $\mathrm{Fe}$ in the samples analyzed. Application of ANOVA Kruskal-Wallis test revealed dependence between sugar biological provenance and its elemental composition. Macro- and microelement levels in chocolates were significantly influenced by the cocoa content in the final product as well as its geographical origin. Factorial and cluster analyses were applied to the data in order to characterize elemental content of the confectionery products. Based on the mineral composition, it was possible to differentiate chemometrically particular types of sugar, cocoa, and chocolates, which is important from the food authenticity point of view.
\end{abstract}

Keywords Confectionery products $\cdot$ Metals $\cdot$ Factor

M. Grembecka $(\square) \cdot$ P. Szefer

Department of Food Sciences, Medical University of Gdansk,

Al. Gen. J. Hallera 107,

PL 80-416, Gdansk, Poland

e-mail: mgrembecka@gumed.edu.pl analysis $\cdot$ Cluster analysis $\cdot$ Food composition $\cdot$ Food authenticity

\section{Introduction}

Chocolates and confectionery products are favored food items of many individuals, especially children. Although these products may be regarded as food items, Dillinger et al. (2000) noted that confectionery products adversely affect mental functions and mood. Confectionery products are usually selected for consumption based upon flavor and textural properties and are often considered as sources of fats and carbohydrates. However, confectionery products are also a source of vitamins, minerals, and even polyphenols and tocopherols, which exert beneficial effects in the prevention of heart disease and possibly some cancers (Steinberg et al. 2003; Suschitzky and Beckett 2008; Vlachopoulos et al. 2006).

Chocolate, the most popular among cocoa products, is reckoned as a luxury good (Szefer and Grembecka 2007). Its composition varies with the type of product. In addition to cocoa, there are many extra ingredients that influence the final composition of the product (Steinberg et al. 2003). Dark chocolates, which possess a high proportion of cocoa solids, are generally considered as a good source of magnesium $(\mathrm{Mg})$ and copper $(\mathrm{Cu})$, whilst milk and white chocolates are relatively good sources of calcium (Ca). Further, due to hydrolysis of phytates during chocolate processing, mineral availability becomes readily available (Steinberg et al. 2003). However, excessive consumption of confectionery products has been associated with increased incidences of type 2 diabetes, obesity, and tooth decay (Anderson 1997). These food items, especially those containing cocoa ingredients, pose a health hazard to 
humans as there might be contamination with high amounts of nickel $(\mathrm{Ni})$, chromium $(\mathrm{Cr})$, lead $(\mathrm{Pb})$, and cadmium (Cd) (Dahiya et al. 2005).

The aim of the present investigation was to analyze and compare concentrations of mineral nutrients in 49 brands of commercially available confectionery products including beet and cane sugar, molasses, maple syrup, cocoa, and dark and milk chocolates. Based on the element concentrations, it was possible to differentiate quantitatively the mineral composition of sugar and confectionery samples and classify them in view of their type, provenance, and level of technological processing.

\section{Materials and Methods}

\section{Samples}

The confectionery samples to be analyzed were purchased from the local market in Gdańsk (Poland). Products including sugar (refined, castor, beet, and cane), molasses, maple syrup, cocoa, and chocolates (dark and milk) were of Polish, European, and American origin. In total, 148 samples were analyzed for macro- and microelements.

\section{Sample Digestion}

Three replicates of each sample weighing approximately $1 \mathrm{~g}$ were treated with $9 \mathrm{ml} 65 \% \mathrm{HNO}_{3}$ (Suprapur ${ }^{\circledR}$ Merck, Darmstadt, Germany) and then digested in an automatic microwave digestion system (MLS 1200 MEGA) according to the following steps: (1) $250 \mathrm{~W}, 48 \mathrm{~s}$; (2) $0 \mathrm{~W}, 48 \mathrm{~s}$; (3) $250 \mathrm{~W}, 6 \mathrm{~min} 24 \mathrm{~s}$; (4) $400 \mathrm{~W}, 4 \mathrm{~min}$; and (5) $650 \mathrm{~W}, 4 \mathrm{~min}$. Every microwave digestion cycle consisted of five food samples and one blank sample $\left(9 \mathrm{ml} 65 \% \mathrm{HNO}_{3}\right)$. After digestion, the vessels were cooled at room temperature. Every digested sample was dissolved up to $10 \mathrm{ml}$ with ultra pure water $\left(18.2 \mathrm{M} \Omega \mathrm{cm}^{-1}\right)$ from a Milli-Q system (Millipore, MA, USA).

\section{Element Analyses}

The concentrations of elements $(\mathrm{Mg}, \mathrm{Ca}, \mathrm{K}, \mathrm{Na}, \mathrm{Zn}, \mathrm{Cu}, \mathrm{Fe}$, $\mathrm{Cr}, \mathrm{Co}, \mathrm{Ni}, \mathrm{Mn}, \mathrm{Pb}$, and $\mathrm{Cd}$ ) were determined in an airacetylene flame by AAS method using deuterium background correction. A PU 9100X model atomic absorption spectrometer (Philips, Great Britain) was used for metal analyses. In all cases, stoichiometric flame air/acetylene was used with the fuel flow of $1.0 \mathrm{~L} / \mathrm{min}$. The FAAS conditions are described in Table 1 . In the case of $\mathrm{Na}$ and $\mathrm{K}$ determinations, Cs (Cesium chloride, Merck, Darmstadt, Germany) was added to samples and standards as an ionization buffer at a concentration of $0.2 \% \mathrm{w} / \mathrm{v}$, and in
Table 1 Experimental conditions for element determination by FAAS

\begin{tabular}{llllll}
\hline Element & $\begin{array}{l}\text { Wavelength } \\
(\mathrm{nm})\end{array}$ & $\begin{array}{l}\text { Burner } \\
\text { width } \\
(\mathrm{cm})\end{array}$ & $\begin{array}{l}\text { Slit } \\
(\mathrm{nm})\end{array}$ & $\begin{array}{l}\text { Lamp } \\
\text { current } \\
(\mathrm{mA})\end{array}$ & $\begin{array}{l}\text { Deuterium } \\
\text { background } \\
\text { correction }\end{array}$ \\
\hline $\mathrm{Mn}$ & 279.5 & 10 & 0.5 & 4 & + \\
$\mathrm{Fe}$ & 248.3 & 5 & 0.2 & 6 & + \\
$\mathrm{Cu}$ & 324.8 & 5 & 0.5 & 3 & - \\
$\mathrm{Zn}$ & 213.9 & 5 & 0.5 & 5 & + \\
$\mathrm{Cr}$ & 357.9 & 10 & 0.5 & 5 & - \\
$\mathrm{Ni}$ & 232.0 & 10 & 0.2 & 5 & + \\
$\mathrm{Co}$ & 240.7 & 10 & 0.2 & 6 & + \\
$\mathrm{Mg}$ & 285.2 & 5 & 0.5 & 4 & + \\
$\mathrm{Ca}$ & 422.7 & 5 & 0.5 & 5 & - \\
$\mathrm{Na}$ & 589.0 & 5 & 0.2 & 6 & - \\
$\mathrm{K}$ & 766.5 & 10 & 0.5 & 5 & - \\
$\mathrm{Pb}$ & 217 & 10 & 0.5 & 6 & + \\
$\mathrm{Cd}$ & 228.8 & 10 & 0.5 & 4 & + \\
\hline
\end{tabular}

the case of $\mathrm{Ca}$ and $\mathrm{Mg}$ measurements, $\mathrm{La}$ (Lanthanum(III) oxide, Merck, Darmstadt, Germany) was used as a releasing agent at a concentration of $0.4 \% w / v$. Phosphorus was determined in the form of phosphomolybdate by spectrophotometric method (Official Methods of Analysis of AOAC International 2002) using Spekol 11 (Carl Zeiss, Jena, Germany).

Lead, $\mathrm{Cd}, \mathrm{Cr}, \mathrm{Ni}$, and $\mathrm{Co}$ contents in the samples analyzed were under the detection limits of the method applied $(\mathrm{Pb}<0.01 \mathrm{mg} / 100 \mathrm{~g}$ w.w., $\mathrm{Cd}<0.003 \mathrm{mg} / 100 \mathrm{~g} \mathrm{w}$. w., $\mathrm{Cr}<0.02 \mathrm{mg} / 100$ g w.w., $\mathrm{Ni}<0.02 \mathrm{mg} / 100 \mathrm{~g}$ w.w., $\mathrm{Co}<$ $0.01 \mathrm{mg} / 100 \mathrm{~g}$ w.w.). The detection limit was established according to Konieczka and Namieśnik (2009), i.e. LD= blank mean $+3 \mathrm{SD}$.

Accuracy of the Analytical Method Used for Quantification

The accuracy of the method used for the determination of the elements was confirmed by analysis of certified standard reference materials including tea (NCS DC 73351), cabbage (IAEA-359), and spinach (IAEA-331) purchased from China National Analysis Centre for Iron and Steel, Beijing (China) and International Atomic Energy Agency (IAEA), respectively. Digestion of these materials was performed with the same decomposition procedure used for confectionery product samples. The results were in agreement with the certified values, as can be seen in Table 2.

Statistics

Correlation analysis, ANOVA Kruskal-Wallis test, factor analysis (FA), and cluster analysis (CA) of the data 
Table 2 Measurements of bioelements and toxic element concentrations in reference materials (tea NCS DC 73351), (cabbage IAEA-359), and (spinach IAEA-331)
${ }^{a}$ Tea NCS DC 73351

${ }^{\mathrm{b}}$ Cabbage IAEA-359

${ }^{\mathrm{c}}$ Spinach IAEA-331

${ }^{\mathrm{d}}$ Informative value

\begin{tabular}{|c|c|c|c|c|}
\hline Element & Concentration declared $[\mu \mathrm{g} / \mathrm{g}]$ & Concentration determined $[\mu \mathrm{g} / \mathrm{g}]$ & Recovery [\%] & $\mathrm{SD}[\%]$ \\
\hline $\mathrm{P}^{\mathrm{a}}$ & 2,840 & $2,910 \pm 197$ & 103 & 6.77 \\
\hline $\mathrm{P}^{\mathrm{b}}$ & 5,180 & $5,340 \pm 83.0$ & 103 & 1.55 \\
\hline $\mathrm{K}^{\mathrm{a}}$ & $16,600 \pm 1,200$ & $15,300 \pm 400$ & 92.2 & 2.61 \\
\hline $\mathrm{K}^{\mathrm{b}}$ & 32,500 & $27,700 \pm 1,000$ & 85.2 & 3.61 \\
\hline $\mathrm{Na}^{\mathrm{a}}$ & $44 \pm 6$ & $38.6 \pm 0.05$ & 88.1 & 0.13 \\
\hline $\mathrm{Na}^{\mathrm{b}, \mathrm{d}}$ & 580 & $490 \pm 43$ & 84.5 & 8.78 \\
\hline $\mathrm{Mg}^{\mathrm{a}}$ & $1,700 \pm 200$ & $1,660 \pm 23.6$ & 97.7 & 1.42 \\
\hline $\mathrm{Mg}^{\mathrm{b}}$ & 2,160 & $2,110 \pm 35.6$ & 97.7 & 1.69 \\
\hline $\mathrm{Ca}^{\mathrm{a}}$ & $4,300 \pm 400$ & $3,160 \pm 50$ & 73.5 & 1.58 \\
\hline $\mathrm{Ca}^{\mathrm{b}, \mathrm{d}}$ & 18,500 & $17,300 \pm 111$ & 93.5 & 0.64 \\
\hline $\mathrm{Zn}^{\mathrm{a}}$ & $26.3 \pm 2.0$ & $25.5 \pm 3.32$ & 96.8 & 13.0 \\
\hline $\mathrm{Zn}^{\mathrm{b}}$ & 38.6 & $37.6 \pm 0.60$ & 97.3 & 1.60 \\
\hline $\mathrm{Fe}^{\mathrm{a}}$ & $264 \pm 15$ & $241 \pm 3.02$ & 91.3 & 1.25 \\
\hline $\mathrm{Fe}^{\mathrm{b}}$ & 148 & $137 \pm 6.6$ & 92.6 & 4.82 \\
\hline $\mathrm{Cu}^{\mathrm{a}}$ & $17.3 \pm 1.8$ & $16.2 \pm 0.76$ & 93.6 & 4.69 \\
\hline $\mathrm{Cu}^{\mathrm{b}}$ & 5.67 & $5.45 \pm 0.02$ & 96.1 & 0.37 \\
\hline $\mathrm{Mn}^{\mathrm{a}}$ & $1,240 \pm 70$ & $1,160 \pm 37.0$ & 93.5 & 3.19 \\
\hline $\mathrm{Mn}^{\mathrm{b}}$ & 31.9 & $32.5 \pm 0.66$ & 102 & 2.03 \\
\hline $\mathrm{Cr}^{\mathrm{a}}$ & $0.80 \pm 0.03$ & $0.77 \pm 0.02$ & 96.3 & 2.60 \\
\hline $\mathrm{Cr}^{\mathrm{b}}$ & 1.3 & $1.15 \pm 0.09$ & 88.5 & 7.83 \\
\hline $\mathrm{Co}^{\mathrm{c}}$ & 0.39 & $0.38 \pm 0.00$ & 97.4 & 0.26 \\
\hline $\mathrm{Ni}^{\mathrm{a}}$ & $4.6 \pm 0.5$ & $4.15 \pm 0.03$ & 90.2 & 0.72 \\
\hline $\mathrm{Ni}^{\mathrm{b}}$ & 1.05 & $0.94 \pm 0.02$ & 89.5 & 2.13 \\
\hline $\mathrm{Pb}^{\mathrm{a}}$ & $4.4+0.3$ & $3.85 \pm 0.27$ & 87.5 & 7.01 \\
\hline $\mathrm{Cd}^{\mathrm{b}}$ & 0.12 & $0.11 \pm 0.00$ & 91.7 & 0.91 \\
\hline
\end{tabular}

obtained were performed using STATISTICA 8.0 for Windows (Copyright ${ }^{(}$StatSoft, Inc. 1984-2007, USA). Before the chemometric analysis, the selected variables were tested for normality. In all cases, they did not follow the normal distribution according to Shapiro-Wilk and the Kolmogorov-Smirnov tests (Brereton 2003; Szefer et al. 2007). Therefore, nonparametric procedures were adapted in our analyses. Prior the chemometric processing, the data matrix was autoscaled. FA was performed on raw data sets concerning confectionery products, cocoa, and chocolate samples. The data matrix was established using the elements as columns and confectionery product samples as rows. Elements such as $\mathrm{Pb}, \mathrm{Cd}, \mathrm{Cr}, \mathrm{Ni}$, and $\mathrm{Co}$ had to be eliminated from the data set because of their too low levels; therefore, nine loadings ( $\mathrm{Ca}, \mathrm{Mg}, \mathrm{Na}, \mathrm{K}, \mathrm{P}, \mathrm{Zn}, \mathrm{Cu}, \mathrm{Fe}$, and $\mathrm{Mn}$ ) constituted the ultimate data matrix.

All elements proved to have great contribution to sample differentiation (Tables 3 and 4). The cutoff loading value to determine which elements will be used at the clustering stage was set at the level $>0.70$. CA, similarly to FA, was also performed on raw data sets concerning confectionery products. The best results of CA analysis were obtained by applying the Ward method as a way of calculating cluster distances as well as Euclidean distance as a measure of distance between the analyzed samples.

\section{Results and Discussion}

\section{Concentration Data}

Data of the elements analyzed in confectionery products are listed in Tables 5 and 6. The metal concentrations in the

Table 3 Factor loadings for each element analyzed in cocoa

\begin{tabular}{lrr}
\hline & \multicolumn{1}{l}{ Factor 1 } & \multicolumn{1}{c}{ Factor 2 } \\
\hline $\mathrm{Ca}$ & -0.191274 & -0.900891 \\
$\mathrm{Mg}$ & -0.938504 & 0.302574 \\
$\mathrm{Na}$ & 0.715136 & 0.669480 \\
$\mathrm{~K}$ & -0.815927 & 0.095511 \\
$\mathrm{P}$ & -0.223382 & -0.912398 \\
$\mathrm{Zn}$ & -0.964871 & 0.216102 \\
$\mathrm{Cu}$ & -0.967391 & 0.079782 \\
$\mathrm{Fe}$ & -0.899810 & 0.167629 \\
$\mathrm{Mn}$ & -0.977895 & 0.057753 \\
\hline
\end{tabular}


Table 4 Factor loadings for each element analyzed in chocolates

\begin{tabular}{lrr}
\hline & \multicolumn{1}{l}{ Factor 1 } & \multicolumn{1}{l}{ Factor 2 } \\
\hline $\mathrm{Ca}$ & 0.755963 & -0.510752 \\
$\mathrm{Mg}$ & -0.944863 & -0.192192 \\
$\mathrm{Na}$ & 0.866994 & -0.233179 \\
$\mathrm{~K}$ & -0.927346 & 0.121370 \\
$\mathrm{P}$ & 0.309070 & 0.806859 \\
$\mathrm{Zn}$ & -0.915320 & -0.213438 \\
$\mathrm{Cu}$ & -0.937358 & -0.166168 \\
$\mathrm{Fe}$ & -0.607166 & 0.298277 \\
$\mathrm{Mn}$ & -0.961928 & -0.103787 \\
\hline
\end{tabular}

samples are characterized by arithmetic mean value, the corresponding standard deviation (SD), and ranges for wet weight basis. In general, sugar samples were found to contain small amounts of the elements analyzed. White refined and castor sugar contained lower amounts of macroand microelements in comparison to beet brown sugar and natural cane sugar (Tables 5 and 6). Higher element levels were determined in natural molasses sugar, i.e., $54.5 \mathrm{mg}$ $\mathrm{Ca}, 68.5 \mathrm{mg} \mathrm{Mg}, 157 \mathrm{mg} \mathrm{Na}, 725 \mathrm{mg} \mathrm{K}, 88.1 \mathrm{mg} \mathrm{P}$, $0.23 \mathrm{mg} \mathrm{Zn}, 0.07 \mathrm{mg} \mathrm{Cu}, 2.65 \mathrm{mg} \mathrm{Fe}, 0.77 \mathrm{mg} \mathrm{Mn}$, and $0.02 \mathrm{mg} \mathrm{Co} / 100 \mathrm{~g}$. It seems to be due to molasses addition to that product. The differences between products of varied botanical origin were observed, i.e., natural cane sugar$6.11 \mathrm{mg} \mathrm{Ca}$ and $3.34 \mathrm{mg} \mathrm{Mg} / 100 \mathrm{~g}$ whereas brown beet sugar-2.05 $\mathrm{mg} \mathrm{Ca}$ and $1.80 \mathrm{mg} \mathrm{Mg} / 100 \mathrm{~g}$ (Table 5). A great variation of elemental composition was noticed in the case of natural cane sugar, especially for macroelements, which might result from the diverse geographical origin of samples (Table 5). According to Mohammed (1999), sugar contained similar levels of $\mathrm{Fe}, \mathrm{Mg}$, and $\mathrm{Mn}$ but lower levels of Zn. Capar and Cunningham (2000) reported that white refined sugar was characterized by levels of $\mathrm{K}$ and $\mathrm{Na}$ lower than $<3.0 \mathrm{mg}$ and $\mathrm{Ca}<2.0 \mathrm{mg} / 100 \mathrm{~g}$. Awadallah et al. (1995) determined Co and Cr levels in sugar to be $0.0001 \mathrm{mg} / 100$ g. However, Awadallah et al. (1995) reported ten times higher levels of Fe $(2.1 \mathrm{mg} / 100 \mathrm{~g})$ and Mn $(0.04 \mathrm{mg} / 100 \mathrm{~g})$. Much higher levels of the analyzed elements in both beet and cane sugar are reported by Souci et al. (2002).

Molasses and maple syrup are liquid confectionery products which are consumed directly or used as sweetening agents especially in North American countries. Molasses and maple syrup are particularly rich in macroelements such as K (466 and $609 \mathrm{mg} / 100 \mathrm{~g}$, respectively) and P (145 and $40 \mathrm{mg} / 100 \mathrm{~g}$, respectively). Similar results were obtained by Stuckel and Low (1996) for $\mathrm{Mg}$ in maple syrup $(16.7 \mathrm{mg} / 100 \mathrm{~g})$. However, Awadallah et al. (1995) determined higher levels of most of the analyzed elements in molasses except for $\mathrm{Zn}, \mathrm{Cu}$, and $\mathrm{Mn}$.

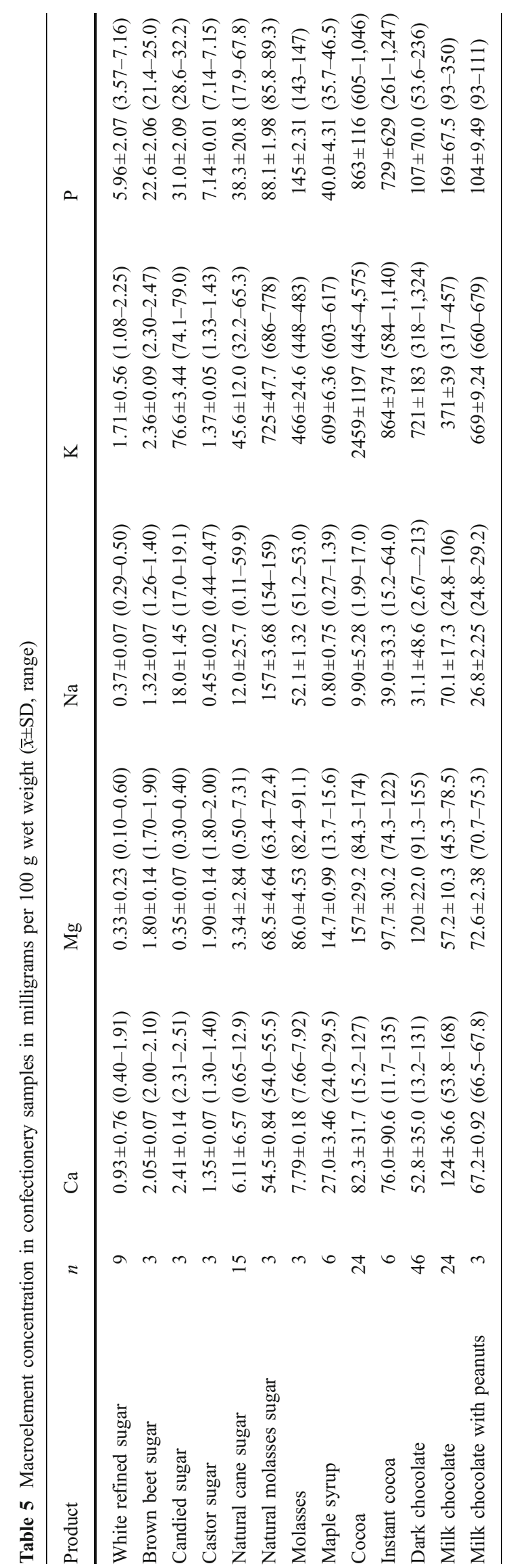




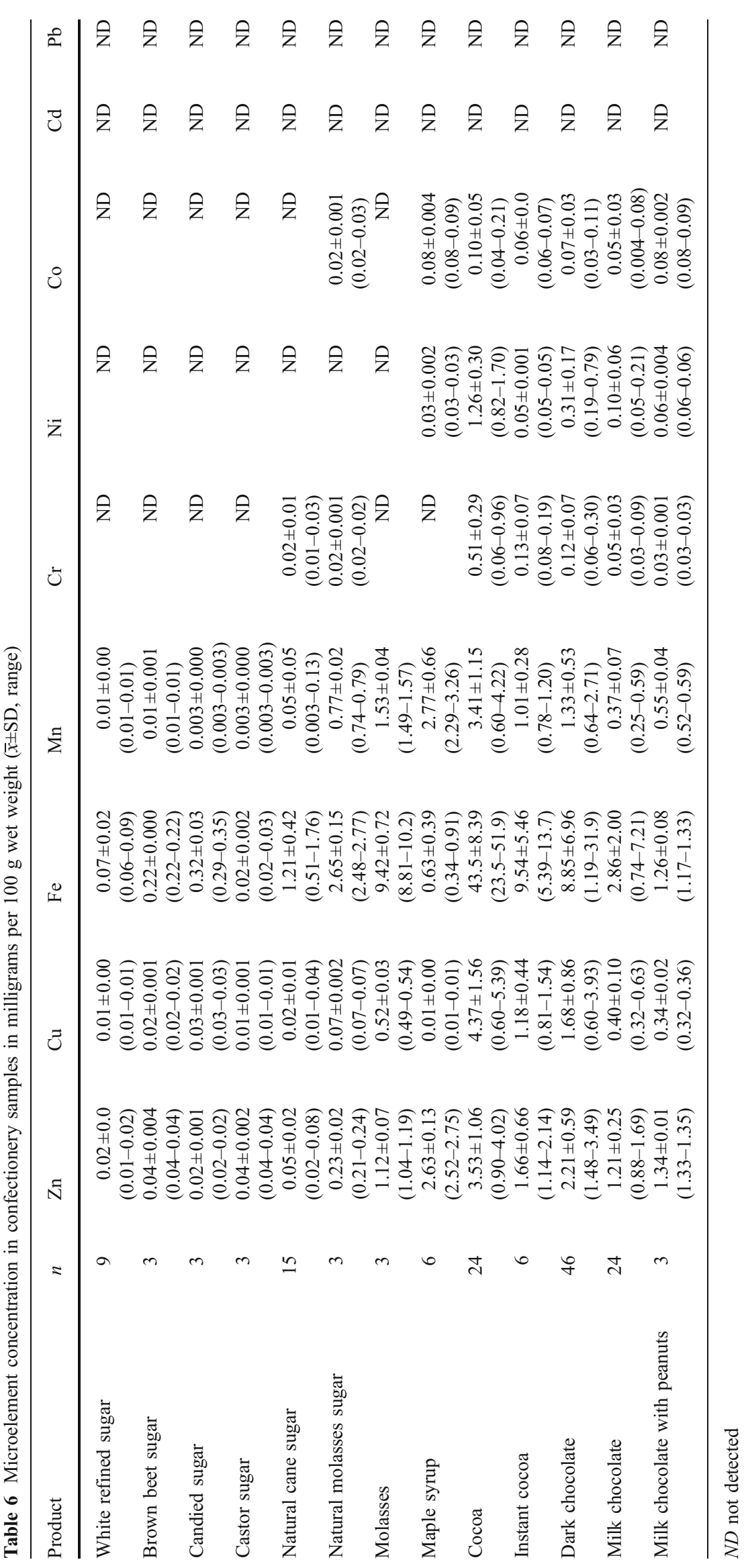


Table 7 Significant correlations between elements in sugar

\begin{tabular}{lll} 
& $\mathrm{Mg}$ & $(+) \mathrm{Ca}^{\mathrm{a}},(+) \mathrm{Zn}^{\mathrm{a}}$ \\
& $\mathrm{Ca}$ & $(+) \mathrm{Mg}^{\mathrm{a}},(+) \mathrm{K}^{\mathrm{a}}$ \\
& $\mathrm{Na}$ & $(+) \mathrm{P}^{\mathrm{a}}$ \\
& $\mathrm{K}$ & $(+) \mathrm{Ca}^{\mathrm{a}},(+) \mathrm{P}^{\mathrm{c}},(+) \mathrm{Fe}^{\mathrm{b}}$ \\
& $\mathrm{P}$ & $(+) \mathrm{K}^{\mathrm{c}},(+) \mathrm{Na}^{\mathrm{a}},(+)$ \\
& & $\mathrm{Fe}^{\mathrm{b}},(+) \mathrm{Zn}^{\mathrm{a}}$ \\
& $\mathrm{Zn}$ & $(+) \mathrm{Mg}^{\mathrm{a}},(+) \mathrm{P}^{\mathrm{a}},(+)$ \\
& & $\mathrm{Fe}^{\mathrm{b}}$ \\
${ }^{(+)}$positive correlation & $\mathrm{Cu}$ & - \\
${ }_{\mathrm{a}} \alpha<0.05$ & $\mathrm{Fe}$ & $(+) \mathrm{K}^{\mathrm{b}},(+) \mathrm{P}^{\mathrm{b}},(+) \mathrm{Zn}^{\mathrm{b}}$ \\
${ }_{\mathrm{b}}^{\mathrm{b}} \alpha<0.01$ & $\mathrm{Mn}$ & - \\
${ }_{\mathrm{c}} \alpha<0.001$ & & \\
\hline
\end{tabular}

Cocoa samples are characterized by varied elemental compositions which might have resulted from different geographical origins and cocoa bean types. The highest average concentration was determined for K $(2460 \mathrm{mg} /$ $100 \mathrm{~g})$ and $\mathrm{Fe}(43.5 \mathrm{mg} / 100 \mathrm{~g})$. This product contained quite high levels of $\mathrm{Ni}(1.26 \mathrm{mg} / 100 \mathrm{~g})$ and $\mathrm{Cr}(0.51 \mathrm{mg} /$ $100 \mathrm{~g}$ ) that can influence the quality of chocolate, especially dark chocolate. On the other hand, instant cocoa samples had lower levels of all elements as compared to powdered cocoa, but it is probably due to technological processing during which most of the bioelements were lost (Tables 5 and 6).

Much higher levels of $\mathrm{Mg}$ and $\mathrm{Ca}$ but lower levels of $\mathrm{Fe}, \mathrm{Mn}$, and $\mathrm{Zn}$ in cocoa samples are reported by Booth et al. (1996). Similarly, Souci et al. (2002) and Kunachowicz et al. (2005) determined smaller amounts of microelements $(\mathrm{Fe}, \mathrm{Cu}, \mathrm{Mn}, \mathrm{Ni}$, and $\mathrm{Cr})$ but greater amounts of macroelements ( $\mathrm{P}, \mathrm{Na}, \mathrm{Mg}$, and $\mathrm{Ca}$ ). According to Falandysz and Kotecka (1993), cocoa contains $4.2 \mathrm{mg}$
$\mathrm{Mn} / 100 \mathrm{~g}, 4.0 \mathrm{mg} \mathrm{Cu} / 100 \mathrm{~g}, 15.0 \mathrm{mg} \mathrm{Zn/100} \mathrm{g,} \mathrm{and}$ $16.0 \mathrm{mg} \mathrm{Fe} / 100 \mathrm{~g}$. Shittu and Badmus (2009) concluded that calcium and phosphorus were the most abundant elements in the cocoa powders. Their composition ranged from 14 to 574 and 0 to $671.0 \mathrm{mg} / 100 \mathrm{~g}$, respectively (Shittu and Badmus 2009).

Chocolate, the most popular among cocoa products, is reckoned as a luxury good (Szefer and Grembecka 2007). There are many kinds of this product, but in our investigations, we focused only on two main categories, i.e., dark and milk. Statistically significant differences in the elemental composition between these two groups were observed (Tables 5 and 6). The main reason for this variation is probably the different cocoa contents of unidentified origin in the final product. Producer states only the percentage of cocoa and even this cannot be reliable as it can be seen in the following sections of this paper in view of the results of cluster analysis. Dark chocolates are characterized by higher concentration of such macroelements as $\mathrm{Mg}(120 \mathrm{mg} / 100 \mathrm{~g})$ and $\mathrm{K}(721 \mathrm{mg} /$ $100 \mathrm{~g}$ ) and all the other analyzed microelements (Table 6). $\mathrm{Ni}$ content in dark chocolates was also greater than in milk chocolates, which might be explained by the greater cocoa content in these products. Similar results to ours are reported by Dahiya et al. (2005), Souci et al. (2002), and Kunachowicz et al. (2005).

Consumption of $100 \mathrm{~g}$ of confectionery products supplies the human body with varied amounts of mineral components. In general, the realization of RDA for an adult was between $12.5 \%$ and $16.4 \%$ for $\mathrm{Mg}, 3.88 \%$ for $\mathrm{Ca}$, $2.15 \%$ for $\mathrm{Na}, 11.5 \%$ for $\mathrm{K}, 25.8 \%$ for $\mathrm{P}, 9.86-13.6 \%$ for $\mathrm{Zn}, 74 \%$ for $\mathrm{Cu}$, and $34.4-62.0 \%$ for $\mathrm{Fe}$. The highest average percentages of realization of RDA for adult (Jarosz

Table 8 Significant correlations between elements in cocoa and chocolates

\begin{tabular}{lll}
\hline Element & Cocoa & Chocolates \\
\hline $\mathrm{Mg}$ & $(-) \mathrm{Na}^{\mathrm{a}},(+) \mathrm{K}^{\mathrm{b}},(+) \mathrm{Zn}^{\mathrm{c}},(+) \mathrm{Cu}^{\mathrm{b}},(+) \mathrm{Cr}^{\mathrm{b}}$ & $(-) \mathrm{Ca}^{\mathrm{a}},(+) \mathrm{K}^{\mathrm{c}},(-) \mathrm{Na}^{\mathrm{b}},(-) \mathrm{P}^{\mathrm{a}},(+) \mathrm{Zn}^{\mathrm{c}},(+) \mathrm{Cu}^{\mathrm{c}},(+) \mathrm{Fe}^{\mathrm{b}},(+) \mathrm{Mn}^{\mathrm{c}},(+) \mathrm{Cr}^{\mathrm{c}}$ \\
$\mathrm{Ca}$ & - & $(-) \mathrm{Mg}^{\mathrm{a}},(+) \mathrm{Na}^{\mathrm{c}},(-) \mathrm{K}^{\mathrm{b}},(-) \mathrm{Zn}^{\mathrm{a}},(-) \mathrm{Cu}^{\mathrm{b}},(-) \mathrm{Fe}^{\mathrm{a}},(-) \mathrm{Mn}^{\mathrm{b}}$ \\
$\mathrm{Na}$ & $(-) \mathrm{Mg}^{\mathrm{a}},(-) \mathrm{Cu}^{\mathrm{a}},(-) \mathrm{Mn}^{\mathrm{a}}$ & $(+) \mathrm{Ca}^{\mathrm{c}},(-) \mathrm{K}^{\mathrm{b}},(-) \mathrm{Mg}^{\mathrm{b}},(-) \mathrm{Zn}^{\mathrm{a}},(-) \mathrm{Cu}^{\mathrm{b}},(-) \mathrm{Fe}^{\mathrm{a}},(-) \mathrm{Mn}^{\mathrm{b}}$ \\
$\mathrm{K}$ & $(+) \mathrm{Mg}^{\mathrm{b}},(+) \mathrm{Zn}^{\mathrm{b}},(+) \mathrm{Cu}^{\mathrm{a}},(+) \mathrm{Fe}^{\mathrm{a}},(+) \mathrm{Mn}^{\mathrm{a}},(+) \mathrm{Cr}^{\mathrm{b}}$ & $(+) \mathrm{Mg}^{\mathrm{c}},(-) \mathrm{Na}^{\mathrm{b}},(-) \mathrm{Ca}^{\mathrm{b}},(+) \mathrm{Zn}^{\mathrm{c}},(+) \mathrm{Cu}^{\mathrm{c}},(+) \mathrm{Fe}^{\mathrm{c}},(+) \mathrm{Mn}^{\mathrm{c}},(+) \mathrm{Cr}^{\mathrm{c}}$ \\
$\mathrm{P}$ & - & $(-) \mathrm{Mg}^{\mathrm{a}},(-) \mathrm{Zn}^{\mathrm{a}},(-) \mathrm{Cu}^{\mathrm{a}},(-) \mathrm{Mn}^{\mathrm{a}},(-) \mathrm{Co}^{\mathrm{a}}$ \\
$\mathrm{Zn}$ & $(+) \mathrm{Mg}^{\mathrm{c}},(+) \mathrm{K}^{\mathrm{b}},(+) \mathrm{Cu}^{\mathrm{a}},(+) \mathrm{Cr}^{\mathrm{c}}$ & $(+) \mathrm{Mg}^{\mathrm{c}},(+) \mathrm{K}^{\mathrm{c}},(-) \mathrm{Ca}^{\mathrm{a}},(-) \mathrm{Na}^{\mathrm{a}},(-) \mathrm{P}^{\mathrm{a}},(+) \mathrm{Cu}^{\mathrm{c}},(+) \mathrm{Fe}^{\mathrm{c}},(+) \mathrm{Mn}^{\mathrm{c}},(+) \mathrm{Cr}^{\mathrm{c}}$ \\
$\mathrm{Cu}$ & $(+) \mathrm{Mg}^{\mathrm{b}},(+) \mathrm{K}^{\mathrm{a}},(-) \mathrm{Na}^{\mathrm{c}},(+) \mathrm{Zn}^{\mathrm{a}},(+) \mathrm{Cr}^{\mathrm{a}}$ & $(+) \mathrm{Mg}^{\mathrm{c}},(+) \mathrm{K}^{\mathrm{c}},(-) \mathrm{Ca}^{\mathrm{b}},(-) \mathrm{Na}^{\mathrm{b}},(-) \mathrm{P}^{\mathrm{a}},(+) \mathrm{Zn}^{\mathrm{c}},(+) \mathrm{Fe}^{\mathrm{c}},(+) \mathrm{Mn}^{\mathrm{c}},(+) \mathrm{Cr}^{\mathrm{c}}$ \\
$\mathrm{Fe}$ & $(+) \mathrm{K}^{\mathrm{a}},(+) \mathrm{Cr}^{\mathrm{a}}$ & $(+) \mathrm{Mg}^{\mathrm{b}},(+) \mathrm{K}^{\mathrm{c}},(-) \mathrm{Ca}^{\mathrm{a}},(-) \mathrm{Na}^{\mathrm{a}},(+) \mathrm{Zn}^{\mathrm{c}},(+) \mathrm{Cu}^{\mathrm{c}},(+) \mathrm{Mn}^{\mathrm{c}},(+) \mathrm{Cr}^{\mathrm{c}}$ \\
$\mathrm{Mn}$ & $(+) \mathrm{K}^{\mathrm{a}},(-) \mathrm{Na}^{\mathrm{a}}$ & $(+) \mathrm{Mg}^{\mathrm{c}},(+) \mathrm{K}^{\mathrm{c}},(-) \mathrm{Ca}^{\mathrm{b}},(-) \mathrm{Na}^{\mathrm{b}},(-) \mathrm{P}^{\mathrm{a}},(+) \mathrm{Zn}^{\mathrm{c}},(+) \mathrm{Cu}^{\mathrm{c}},(+) \mathrm{Fe}^{\mathrm{c}},(+) \mathrm{Cr}^{\mathrm{c}}$ \\
$\mathrm{Cr}$ & $(+) \mathrm{Mg}^{\mathrm{b}},(+) \mathrm{K}^{\mathrm{b}},(+) \mathrm{Zn}^{\mathrm{c}},(+) \mathrm{Cu}^{\mathrm{a}},(+) \mathrm{Fe}^{\mathrm{a}}$ & $(+) \mathrm{Mg}^{\mathrm{c}},(+) \mathrm{K}^{\mathrm{c}},(+) \mathrm{Zn}^{\mathrm{c}},(+) \mathrm{Cu}^{\mathrm{c}},(+) \mathrm{Fe}^{\mathrm{c}},(+) \mathrm{Mn}^{\mathrm{c}}$ \\
$\mathrm{Co}$ & - & $(-) \mathrm{P}^{\mathrm{a}}$ \\
\hline
\end{tabular}

$(+)$ positive correlation, $(-)$ negative correlation

${ }^{\mathrm{a}} \alpha<0.05$

${ }^{\mathrm{b}} \alpha<0.01$

${ }^{\mathrm{c}} \alpha<0.001$ 
Table 9 The influence of the product type, its botanical and geographical provenance on elemental composition in view of ANOVA KruskalWallis test

\begin{tabular}{lccccccccccc}
\hline Product & $\mathrm{Mg}$ & $\mathrm{Ca}$ & $\mathrm{Na}$ & $\mathrm{K}$ & $\mathrm{P}$ & $\mathrm{Zn}$ & $\mathrm{Cu}$ & $\mathrm{Fe}$ & $\mathrm{Mn}$ & $\mathrm{Cr}$ & $\mathrm{Co}$ \\
\hline $\begin{array}{l}\text { Sugar } \\
\text { Beet, cane }\end{array}$ & 2.70 & 1.63 & 0.03 & 3.33 & $4.03^{\mathrm{a}}$ & $4.03^{\mathrm{a}}$ & 0.53 & $7.50^{\mathrm{b}}$ & 1.63 & - \\
$\begin{array}{l}\text { Cacao } \\
\text { Powder, instant }\end{array}$ & 3.34 & 0.00 & 3.34 & 2.45 & 0.00 & 2.45 & 2.45 & $4.36^{\mathrm{a}}$ & 2.45 & 2.45 & 1.09 \\
$\begin{array}{l}\text { Chocolates } \\
\text { Dark, milk }\end{array}$ & $13.7^{\mathrm{c}}$ & $9.84^{\mathrm{b}}$ & $10.3^{\mathrm{b}}$ & $11.2^{\mathrm{c}}$ & $5.91^{\mathrm{a}}$ & $12.2^{\mathrm{c}}$ & $13.7^{\mathrm{c}}$ & $8.56^{\mathrm{b}}$ & $13.7^{\mathrm{c}}$ & $7.75^{\mathrm{b}}$ & 2.98 \\
$\begin{array}{l}\text { Provenance } \\
\text { Poland, imported }\end{array}$ & 0.79 & 1.81 & 0.91 & 0.57 & 2.38 & 0.05 & 0.13 & $4.28^{\mathrm{a}}$ & 0.00 & 0.91 & 0.00 \\
\hline
\end{tabular}

The results are expressed as test value $(\mathrm{H})$

${ }^{\mathrm{a}} \alpha<0.05$

${ }^{\mathrm{b}} \alpha<0.01$

${ }^{\mathrm{c}} \alpha<0.001$

and Buthak-Jachymczyk 2008) were obtained for cocoa and its products, especially dark chocolates.

In accordance with the recommendation of Food and Agriculture Organization of the United Nations/World Health Organization (FAO/WHO) (WHO 2010a; b), a provisional tolerable monthly intake (PTMI) for $\mathrm{Cd}$ amounted to $25 \mu \mathrm{g} / \mathrm{kg}$ of body weight for adult, i.e., $490 \mu \mathrm{g}$ monthly for a $70-\mathrm{kg}$ person. At the 73rd FAO/WHO Meeting (WHO 2010b), the Committee concluded that the provisional tolerable weekly intake (PTWI) for $\mathrm{Pb}$ could no longer be considered health protective and withdrew it. Furthermore, as the dose-response analyses did not provide any indication of a threshold for the key adverse effects of lead, the Committee concluded that it was not possible to establish a new PTWI that would be health protective (WHO 2010b). However, as levels of these two elements in all the samples analyzed were $<45 \mu \mathrm{g} / 100 \mathrm{~g}$ and $<15 \mu \mathrm{g} /$

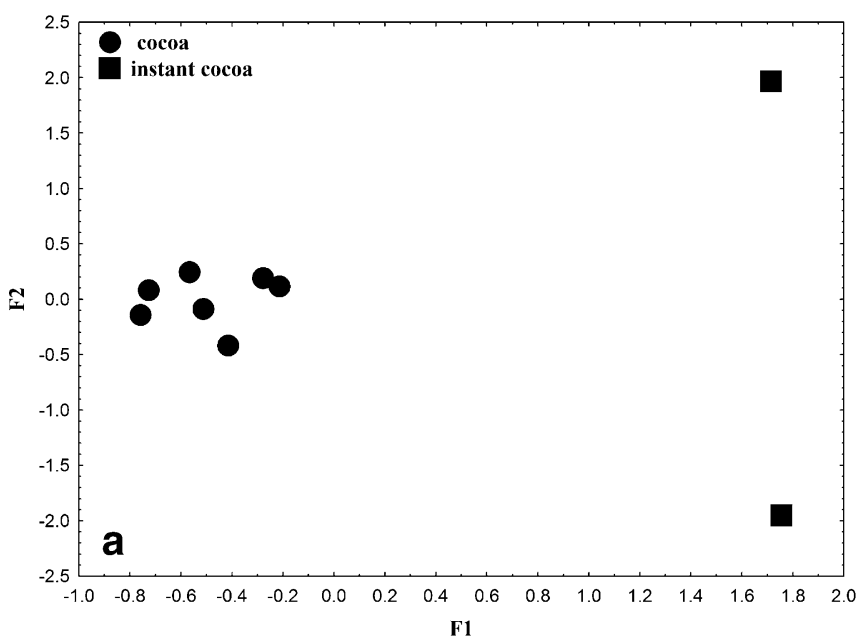

$100 \mathrm{~g}$ for $\mathrm{Pb}$ and $\mathrm{Cd}$, respectively, it means that they do not exceed PTMIs. Therefore, it was concluded that there is no health hazard associated with consumption of sugar and confectionery products.

\section{Statistical Estimate}

\section{Correlation}

Statistically significant correlations $(\alpha<0.001, \alpha<0.001$, and $\alpha<0.05$ ) between concentrations of the metals studied in confectionery products are listed in Tables 7 and 8. The analyzed samples before Spearman correlation analysis were divided into three groups, i.e., sugar, cocoa, and chocolates. The most significant relationships in sugar samples were noted for the following pairs of elements: $\mathrm{K}-\mathrm{P}(\alpha<0.001), \mathrm{K}-\mathrm{Fe}, \mathrm{P}-\mathrm{Fe}$, and Zn-Fe $(\alpha<0.01$; Table 7$)$.

Fig. 1 a. Scatterplot of object scores of the two discriminant functions of cocoa samples. b. Scatterplot of loadings for nine elements in cocoa samples 
As can be seen in Table 8 , the majority of chemical elements exhibited significant positive and negative correlations between their concentrations in cocoa and chocolate samples. Significant positive relationships $(\alpha<0.001)$ were observed for the following assemblages: $\mathrm{Mg}-\mathrm{K}-\mathrm{Zn}-\mathrm{Cu}-$ $\mathrm{Fe}-\mathrm{Mn}-\mathrm{Cr}$, while in cocoa, they were noted in the case of pairs such as $\mathrm{Mg}-\mathrm{Zn}$ and $\mathrm{Zn}-\mathrm{Cr}$ (Table 8).

\section{ANOVA Kruskal-Wallis Test}

The influence of the type, botanical and geographical provenance on the products' elemental composition was verified by Kruskal-Wallis test. The results are presented in Table 9. There was a statistically significant influence of botanical origin of sugar samples (cane and beet) on $\mathrm{Fe}(\alpha<$ $0.001)$, and $\mathrm{P}$ and $\mathrm{Zn}(\alpha<0.05)$. The final form of the product had an influence on $\mathrm{Fe}$ content in cocoa samples $(\alpha<0.04)$. Levels of most of the analyzed elements in chocolates strongly depended on their type (dark/milk;
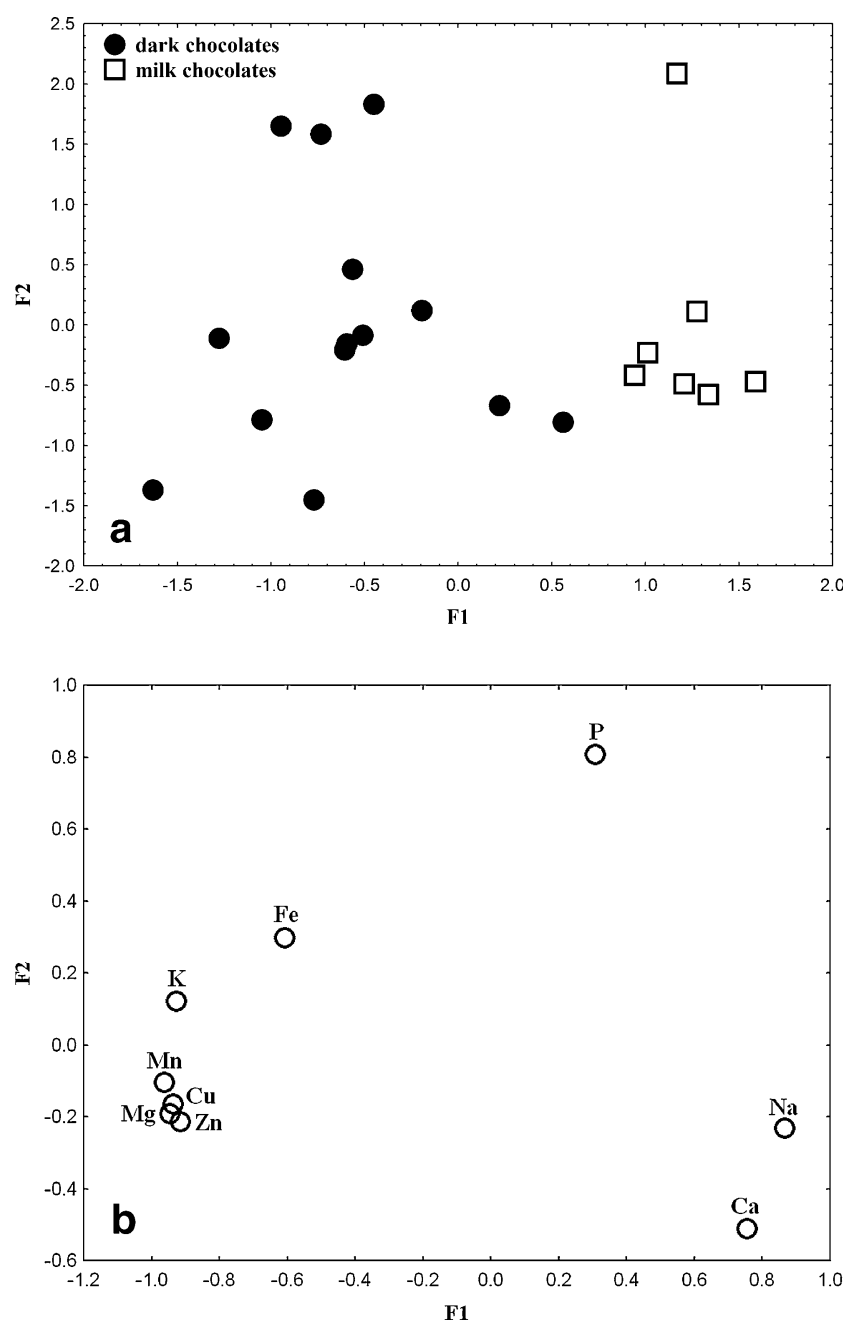

Fig. 2 a. Scatterplot of object scores of the two discriminant functions of chocolate samples. b. Scatterplot of loadings for nine elements in chocolate samples

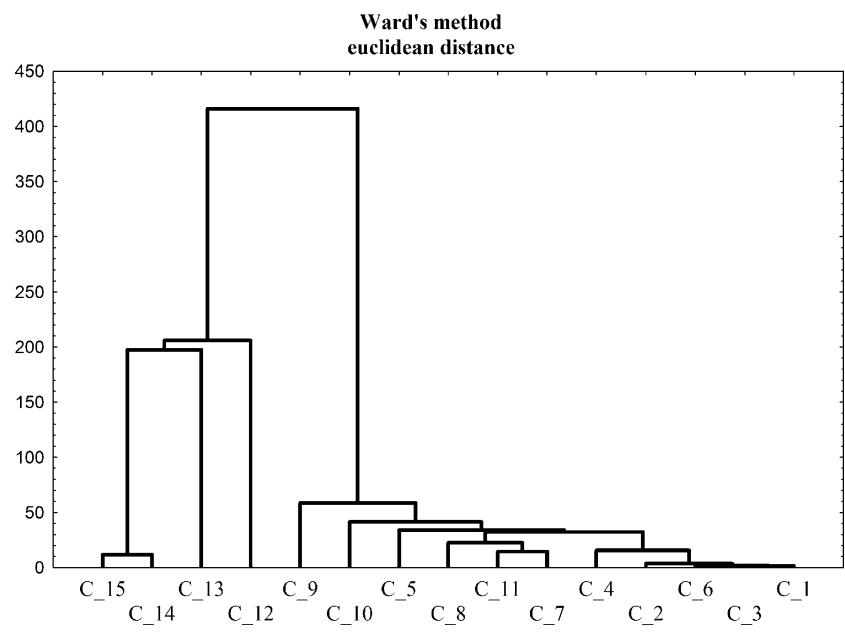

Fig. 3 Hierarchical dendrogram for the analyzed samples of sugar and other confectionery products as objects

Table 9). The cocoa content in the chocolate had a statistically significant influence on concentrations of $\mathrm{Mg}$, $\mathrm{K}, \mathrm{Zn}, \mathrm{Cu}, \mathrm{Mn}(\alpha<0.001)$ as well as $\mathrm{Ca}, \mathrm{Na}, \mathrm{Fe}$, and $\mathrm{Cr}(\alpha<$ $0.01)$. Moreover, Fe level was dependent on the geographical provenance of the product $(\alpha<0.03$; Table 9).

\section{Factor Analysis and Cluster Analysis}

Factor analysis was performed on raw data sets concerning cocoa and chocolate samples. The data obtained after processing metal concentrations by factor analysis for all the cocoa samples analyzed are illustrated in Fig. 1a, b while for chocolates in Fig. 2a, b.

In order to visualize the data structure concerning cocoa samples, a factor analysis was carried out, and the results

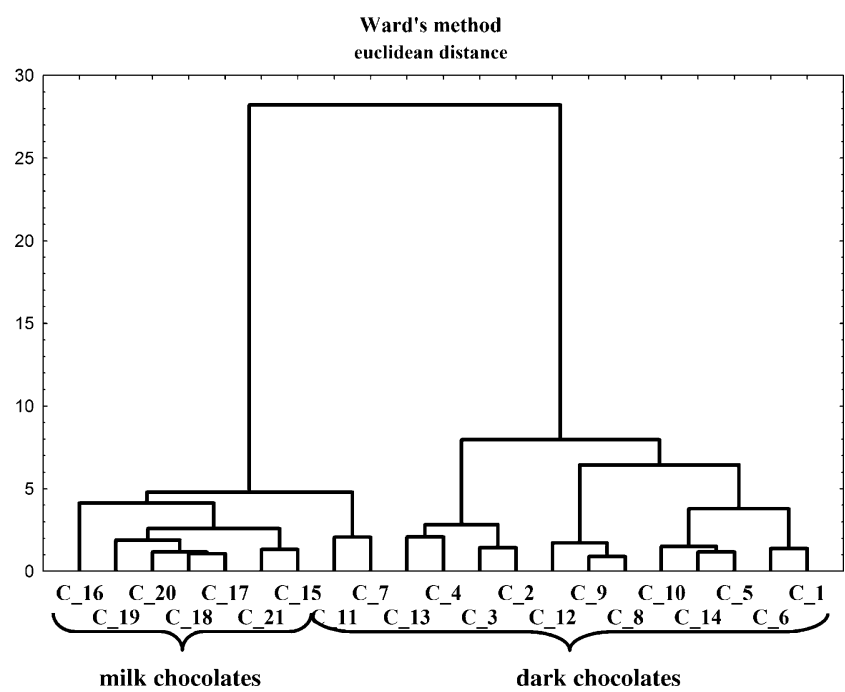

Fig. 4 Hierarchical dendrogram for the analyzed samples of chocolate as objects $(C 1-C 14$, dark chocolates; $C 2-C 4$ and $C 13$, chocolates with cocoa content $>70 \% ; C 7$ and $C 11$, chocolates with cocoa content at least $45 \%$; $C 15-C 21$, milk chocolates) 
are depicted in Fig. 1a, b. The two factors (F1 and F2) issued from FA explain cumulatively up to $89.5 \%$ of the total variance, so that $64.2 \%$ is explained by $\mathrm{F} 1$ and $25.3 \%$ by F2. The eigenvalues are 5.78 (F1) and 2.28 (F2), respectively. Factor loadings for the elements analyzed are presented in Table 3. Figure 1a shows the scatterplot for the studied samples. In order to identify the elements responsible for the grouping of the objects (cocoa), biplot of loadings was drawn for F1-F2 (Fig. 1b). As can be seen in Fig. 1, higher values of F1 correspond to instant cocoa samples characterized by the highest levels of $\mathrm{Na}$, whereas lower ones to cocoa powder containing great concentrations of $\mathrm{Mg}, \mathrm{K}, \mathrm{Zn}, \mathrm{Cu}, \mathrm{Fe}$, and $\mathrm{Mn}$.

Application of FA model to data from multielemental analysis of chocolate samples indicated differences between dark and milk ones. The results for the chocolate data set are presented in Fig. 2a, b. The first two factors explain cumulatively $81.9 \%$ of the total variance; F1 and F2 account for $68.7 \%$ and $13.2 \%$, respectively. The eigenvalues are 6.18 (F1) and 1.19 (F2), respectively. Factor loadings for the elements analyzed are presented in Table 4. Factor 1 is responsible for differentiation of two types of chocolates. Dark chocolates are characterized by lower values of F1 (Fig. 2a) and greater concentration of such elements as $\mathrm{Mg}, \mathrm{K}, \mathrm{Zn}, \mathrm{Cu}, \mathrm{Fe}$, and $\mathrm{Mn}$. Higher values of $\mathrm{F} 1 \mathrm{can}$ be associated with milk chocolates which are richer in $\mathrm{Ca}, \mathrm{Na}$, and P (Fig. 2b).

The CA data (hierarchical clustering, Ward's method) for beet, cane sugar, and other confectionery products such as maple syrup and molasses as objects are shown in Fig. 3. The dendrogram is built up of two main clusters. The first contains objects $\mathrm{C} 12-\mathrm{C} 15$, which represent other confectionery products including molasses and maple syrup, whereas the latter represents sugar samples. It is also possible to distinguish two subclusters in the sugar one. The first of them contains samples $(\mathrm{C} 1-\mathrm{C} 4, \mathrm{C} 6)$ representing refined beet sugar, while the second $(\mathrm{C} 7-\mathrm{C} 11, \mathrm{C} 5)$, the natural cane sugar samples. Therefore, it can be concluded that this technique is able, based on mineral composition, to distinguish samples not only of varied types but also in view of their botanical provenance as well as level of technological processing. There are few data concerning the application of these techniques to confectionery products. However, Awadallah et al. (1995) successfully classified sugar samples in view of their provenance from different factories using cluster analysis.

Hierarchical dendrogram for the analyzed samples of chocolate as objects is depicted in Fig. 4. There can be distinguished two main clusters, the first one (C1-C14) contains objects representing dark chocolates, while the second, milk chocolates. Dark chocolates were assigned to subclusters representing products with cocoa content $>70 \%$ $(\mathrm{C} 2-\mathrm{C} 4, \mathrm{C} 13)$ and others. However, dark chocolates with cocoa content at least $45 \%(\mathrm{C} 7, \mathrm{C} 11)$ were assigned to the cluster of milk chocolates (C15-C21), which might signify that the products contain less of cocoa than was stated on the label by the producer. These results have shown that there is a possibility of CA application in fraud detection.

\section{Conclusions}

Based on the obtained results, it can be concluded that multivariate techniques are efficient tools that can be successfully applied to food quality and authenticity evaluation. In this paper, loadings such as $\mathrm{Ca}, \mathrm{Mg}, \mathrm{Na}, \mathrm{K}$, $\mathrm{P}, \mathrm{Zn}, \mathrm{Cu}, \mathrm{Fe}$, and $\mathrm{Mn}$ were good descriptors for different kinds of chocolates and other confectionery products. Their application was helpful for deeper understanding of the distribution of selected metals in food.

Application of ANOVA Kruskal-Wallis test enabled us to reveal dependence between sugar biological provenance and its elemental composition. Macro- and microelement levels in chocolates were significantly influenced by the cocoa content in the final product as well as its geographical origin. Other chemometric techniques such as factor and cluster analyses have proved to be reliable tools in differentiation of food products in view of their mineral composition. Moreover, cluster analysis enabled us to separate chocolate samples of different cocoa contents within the same group, which might be very helpful in detecting fraud or proving authenticity of the product.

Dark chocolates, cocoa, molasses, maple syrup, and nonrefined sugar proved to be products that might not only provide significant amounts of energy but also of essential nutrients such as $\mathrm{Mg}, \mathrm{K}, \mathrm{Zn}, \mathrm{Cu}, \mathrm{Fe}$, and $\mathrm{Mn}$. However, cocoa products can also be a source of $\mathrm{Ni}$ and $\mathrm{Cr}$ in our diets so their quality should be constantly monitored in order to prevent heavy metal poisoning.

Acknowledgements The authors gratefully acknowledge financial support received from grant PB 0676/P052005/28 from the Polish Ministry of Scientific Research and Information Technology. Thanks are also due to Edyta Tomczak for her assistance in sample preparation.

Open Access This article is distributed under the terms of the Creative Commons Attribution Noncommercial License which permits any noncommercial use, distribution, and reproduction in any medium, provided the original author(s) and source are credited.

\section{References}

Anderson GH (1997) Nutr Res 17:1485

Awadallah RM, Ismail SS, Mohamed AE (1995) J Radioanal Nucl Chem 196:377

Booth CK, Reilly C, Farmakalidis E (1996) J Food Comp Anal 9:135

Brereton RG (2003) Chemometrics: data analysis for the laboratory and chemical plant. Wiley, Chichester

Capar GS, Cunningham WC (2000) J AOAC Int 83:157 
Dahiya S, Karpe R, Hegde AG, Sharma RM (2005) J Food Comp Anal 18:517

Dillinger TL, Barriga P, Escárcega S, Jimenez M, Lowe DS, Grivetti LE (2000) J Nutr 130:2057S

Falandysz J, Kotecka W (1993) Bromat Chem Toksykol 26:285, in Polish with English summary

Jarosz M, Bułhak-Jachymczyk B (2008) Normy żywienia człowieka. Podstawy prewencji otyłości i chorób niezakaźnych. PZWL, Warszawa (in Polish)

Konieczka P, Namieśnik J (2009) Quality assurance and quality control in the analytical chemical laboratory: a practical approach. CRC Press, Boca Raton

Kunachowicz H, Nadolna I, Przygoda B, Iwanow K (2005) Tabele składu i wartości odżywczej żywności. PZWL, Warszawa (in Polish)

Mohamed AE (1999) Food Chem 65:503

Official Methods of Analysis of AOAC International (2002) Official Method 991.25. Calcium, magnesium, and phosphorus in cheese -atomic absorption spectrophotometric and colorimetric method. 17th Ed., Rev 1, AOAC International, Gaithersburg, MD, USA

Shittu TA, Badmus BA (2009) J Food Comp Anal 22:212
Souci SW, Fachmann H, Kraut H (2002) Food composition and nutrition tables. Medpharm Scientific Publishers, Stuttgart

Steinberg FM, Bearden MM, Keen CL (2003) J Am Diet Assoc 103:215

Stuckel JG, Low NH (1996) Food Res Int 29:373

Suschitzky H, Beckett ST (2008) The science of chocolate. Royal Society of Chemistry, Great Britain

Szefer P, Grembecka M (2007) In: Szefer P, Nriagu JO (eds) Mineral components in foods. CRC Press \& Taylor Francis Group, Boca Raton

Szefer P, Nriagu JO (eds) (2007) Mineral components in foods. CRC Press \& Taylor Francis Group, Boca Raton

Vlachopoulos C, Alexopoulos N, Stefanadis C (2006) Curr Hypertens Rep 8:205

WHO (2010a) 72nd Meeting of the Joint FAO/WHO Expert Committee on Food Additives. Rome, 16-25 February 2010. http://www.who.int/foodsafety/chem/summary72_rev.pdf. Accessed 7 Nov 2010

WHO (2010b) 73rd Meeting of the Joint FAO/WHO Expert Committee on Food Additives. Geneva, 8-17 June 2010. http:// www.who.int/foodsafety/publications/chem/summary73.pdf. Accessed 7 Nov 2010 